\title{
BIONIC PRINCIPLES OF SPACE OPTIMIZATION APPLIED IN THE PRODUCT DESIGN PROCESS
}

\author{
Nikola Gerasimovski, Elena Angeleska, Sofija Sidorenko \\ Faculty of Mechanical Engineering, "Ss. Cyril and Methodius" University in Skopje, \\ P.O. box 464, MK-1001, Skopje, Republic of North Macedonia \\ sofija.sidorenko@mf.edu.mk
}

\begin{abstract}
A b s t r a c t: The main goal of the research presented in this paper is providing multi-functionality and space optimization of products by exploring and applying modern bionic and design principles. The specific design issue that needed to be addressed was - design of a multifunctional mountain hiking backpack that allows optimal use of space and maximal comfort when being used. An ideal solution to this stated problem was accomplished by following several phases in the process: study of available literature in the areas of multifunctionality, adaptability and product optimization; analysis of bionic phenomena which were the basic inspiration for creating a modular and compact design; detailed analysis of ergonomic aspects and anthropometric measurements; recognition of the target group and market analysis; materials analysis; development of design solutions and selection of the most suitable concept according to its strongest fulfillment of the given design requirements; elaboration of the final concept and its evaluation.
\end{abstract}

Key words: bionics; biologically inspired design; ergonomics; multi-functionality; modularity; optimization of space

\section{БИОНИЧКИ ПРИНЦИПИ ЗА ОПТИМИЗАЦИЈА НА ПРОСТОРОТ ПРИМЕНЕТИ ВО ПРОЦЕСОТ НА ДИЗАЈНИРАЊЕ}

А п с т р а к т: Главна цел на овој труд е преку истражување и примена на современите бионички методи и принципи на дизајнирање да се изнајдат ефикасни начини за обезбедување мултифункционалност и оптимизација на просторот кај производите. Конкретниот дизајнерски проблем за кој беше потребна анализа на споменатите принципи е креацијата на мултифункционален ранец за планинарење, кој овозможува оптимално искористување на просторот и максимална удобност при негова употреба. Добивање идеално решение на овој проблем беше постигнато низ неколку фази: проучување на расположлива литература од областите на мултифункционалност, адаптибилност и оптимизација на просторот кај производите; анализа на бионички феномени кои беа основна инспирација за креирање модуларен и компактен дизајн; детална анализа на ергономските аспекти и антропометриски мерки; анализа на целната група и пазарот; анализа на материјали; разработка на идејни решенија и избор на најсоодветен концепт според најсилно задоволување на зададените дизајнерски барања; разработка на финалниот концепт и негова евалуација.

Клучни зборови: бионика; биолошки инспириран дизајн; ергономија; мултифункционалност; модуларност; оптимизација на простор

\section{INTRODUCTION}

Space optimization, modularity and multifunctionality are complex design principles that allow creation of useful products that satisfy various target group requirements and they could be adjusted for optimal utilization by a wide range of users.
Therefore, these principles provide guidance in the development of new products with an extended life cycle in accordance of the fast growing "circular design model" trend.

Parkinson, Balling and Hedengren [1] define optimization as the process of determining the best design and explain the basics of the process. In order 
to optimize, the first step is to create a valid, accurate model of the design problem. Besides a model, variables which are free to be adjusted and criteria (objectives and constraints) to be optimized are also required. The objectives represent goals to be maximized or minimized and constraints are limitations. The design variables of the model are adjusted in order to achieve objectives and satisfy constraints.

Modularity is another crucial design principle which aim is to assist creation of flexible products with low sensitivity to change. These modular products have multiple benefits: reduced production costs, simplified design updates and reparations, increased product diversity, reduced transportation time and costs, easier testing etc. Designers and engineers have developed numerous methods for creating modular products. The Modular Function Deployment (MFD) [2] differs from other product building methods by providing a comprehensive approach that takes into account the requirements of all stakeholders in relation to the product development. It suggests following 5 steps: defining user requirements, choosing technical solutions, generating concepts, grading concepts and improvement of the modules. Creating a modular design helps maintaining the complexity of the product at a low level, good deployment of the functions and structure of the interface.

In the last decade, there is a drastic increase in the demand for products with added value, that need to be easy to use, comfortable, flexible to changes and with modern aesthetics - or in one word, multifunctional. Multi-functionality can be achieved by combining many aspects in the design process such as: following the latest technologies of materials and production, in-depth analysis of the target group, creating models of the products, testing their performance and evaluating results. A well-designed multifunctional product will increase the feelings of satisfaction and comfort when being used. The overall comfort is defined as 'a pleasant state, physiological, psychological and physical harmony between a human being and the environment' [3] and plays a great role in product design.

All mentioned design principles were recognized as crucial for a successful design of a hiking backpack and were therefore followed as a guide in the process of concept generation. They were applied by using bionic design strategies, detailed study of the market, ergonomic analysis, study of the latest technologies for backpack production and study of the user needs.

\section{PRINCIPLES OF SPACE OPTIMIZATION DISCOVERED IN NATURE}

Bionic design is a tool that provides functional principles and forms of nature as an inspiration for generating concepts and product development.

Bionic methods in the process of product design are applied by two common approaches:

$>$ Process guided by a bionic solution that inspires how to solve an existing design problem.

$>$ Process guided by a given design problem for which a solution is searched in biological systems.

Versos and Coelho propose the bi-directional bionic design method [4] and Helms [5] suggests that in order to find solutions designers must redefine and restructure the problem and functions to bring them closer to similar problems in nature and see how they are solved by natural organisms. Always ask the question 'how does nature do or doesn't do it'.

The bionic method of Versos and Coelho [4] was adopted for further application in order to study bionic examples and receive knowledge that can provide answers that will help achieve the set designer goals. This was done by the following steps:

1) Defining the designer problem - 'How to ensure maximum utilization of space?'

2) Restructuring the problem in several functions (Table 1).

3) Asking questions about how those restructured functions might be solved in nature (Table 1).

4) Analyzing natural examples (Table 2).

5) Defining solutions and drawing conclusions (Table 3).

6) Application of the nature inspired solutions in design concepts.

Table 1

Redefining the design problem (steps 2 and 3)

\begin{tabular}{ll}
\hline \hline $\begin{array}{l}\text { Decomposition of the } \\
\text { design problem }\end{array}$ & How does nature do it? \\
\hline $\begin{array}{l}\text { Shape and size } \\
\text { transformation }\end{array}$ & $\begin{array}{l}\text { How do living organisms change } \\
\text { their size and shape to adjust to } \\
\text { change of events? }\end{array}$ \\
$\begin{array}{l}\text { Modular composition } \\
\text { and compact structure }\end{array}$ & $\begin{array}{l}\text { How does nature provide com- } \\
\text { pact structures? What kinds of } \\
\text { elements are natural organisms } \\
\text { composed of? }\end{array}$ \\
Multi-functionality & $\begin{array}{l}\text { How do living organisms achi- } \\
\text { eve multi-functionality? }\end{array}$ \\
\hline \hline
\end{tabular}


T a b le 2

\section{Finding solutions in nature (step 4)}

Shape and size transformation

Pangolins change their shape when they feel threatened by curling up into a tight, impenetrable ball to protect their tender undersides.
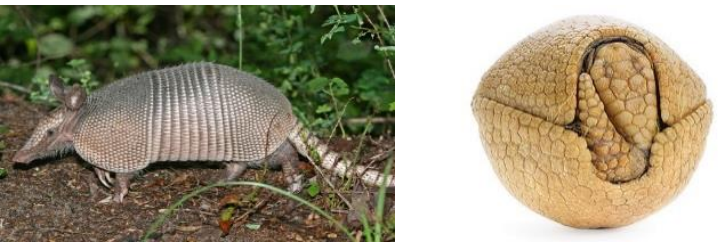

Armadillos have a similar strategy like pangolins - curling in a sphere is their defence tactic.
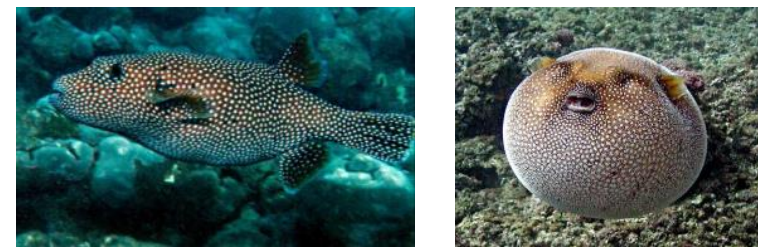

Puffer fish use a reversed method. They maintain a compact shape and when threatened 'inflate' into a virtually inedible ball several times their normal size.

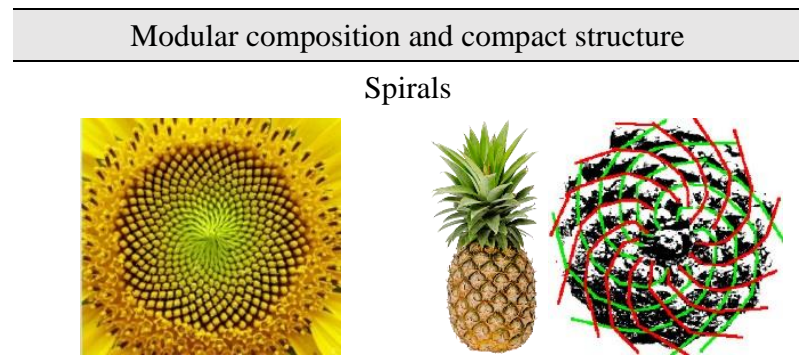

Arrangement of sunflower seed Spiral structure of pineapples

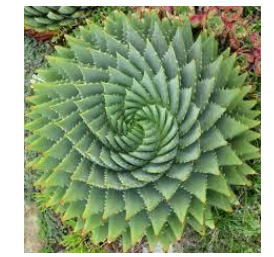

Spiral structure of aloe

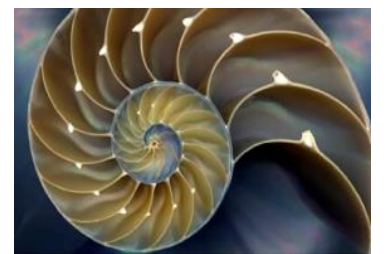

Spiral snail shell

Symmetry

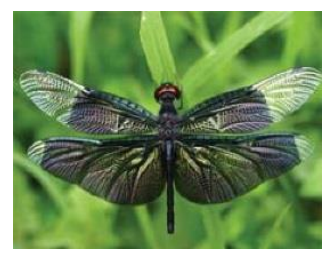

Bilateral symmetry of insects

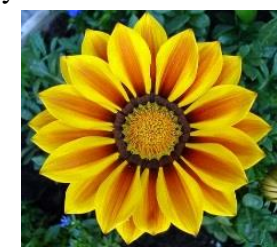

Radial symmetry of flowers
Fractals

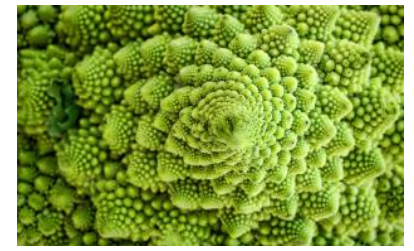

Romanesco broccoli-fractals

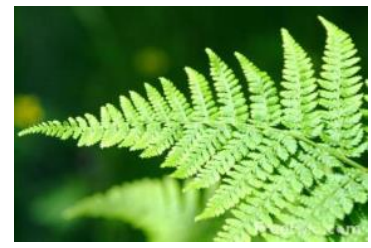

Fern - fractal pattern
Tessellations

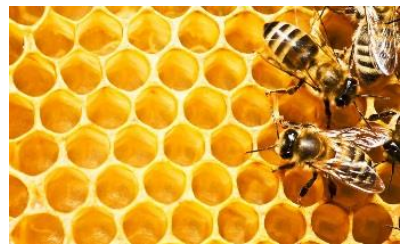

Honeycombs tessellation of hexagons

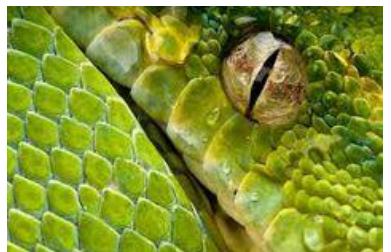

Tessellation pattern of snake and lizard skin
Natural organisms show us how compact complex shapes can be achieved by a regular repetition of geometric elements. Natural patterns are formed spontaneously from the forces that act in the physical world, and at the most basic level these patterns can often be described using the same mathematical and physical principles [6].

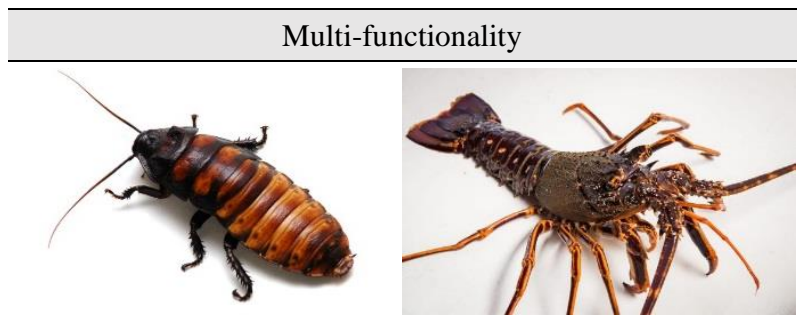

Multi-functionality provides saving resources, material and space and it is a common principle in nature. For example, cockroaches and crabs use exoskeletons as a support - it is an attachment framework for their musculature and at the same time it has a role in defence from pests and predators.

T a b le 3

Conclusions from the bionic research (step 5)

\begin{tabular}{ll}
\hline \hline & $\begin{array}{l}\text { The main volume of the backpack needs to } \\
\text { have elements contained within itself to } \\
\text { enable compact design and small size. } \\
\text { transformation }\end{array}$ \\
$\begin{array}{l}\text { Size enlargement can be achieved by } \\
\text { opening the contained elements one by } \\
\text { one to gradually increase the volume. }\end{array}$ \\
$\begin{array}{l}\text { A modular } \\
\text { composition and } \\
\text { compact structure } \\
\text { simplifying the design to basic geometric } \\
\text { shapes and then attaching them together. }\end{array}$ & $\begin{array}{l}\text { By doing so, the use would be simplified } \\
\text { and the design multifunctional. }\end{array}$ \\
Multi- & $\begin{array}{l}\text { Thinking of ways in which the basic mo- } \\
\text { dular and constructive elements of the } \\
\text { backpack can serve more than one func- } \\
\text { tion will help in maximum use of the space } \\
\text { and adding product value. }\end{array}$ \\
\hline \hline
\end{tabular}


The drawn conclusions from the bionic research helped for better understanding of the principles of space optimization and they were used as design guides later on in the process.

\section{ERGONOMIC ASPECTS OF BACKPACK DESIGN}

\section{A) Ergonomic criteria for designing backpacks}

Even though studies of ergonomics of school backpacks are most common, all of them provide valuable information about the crucial aspects that need to be considered in order to design a comfortable backpack that won't deform the users posture.

A study [7] of mountain backpacks was conducted in order to analyze the impact of the backpack use on the muscles of the body and the tension of the user's heart muscles. The study was performed with 10 male and 10 female subjects, three most commonly used mountain hiking backpacks, and modern laboratory techniques (EMG, EKG, NBM). Results showed that users feel pain when using the backpacks - in the right shoulder (90\%), in the left shoulder $(83.33 \%)$ and in the back $(60 \%)$. The study, as a conclusion, offers a useful list of recommendations for designers to follow in order to create ergonomic backpacks. The backpacks should be designed according to following:

1) possession of a head restraint for the condition when the body leans forward;

2) possession of a backrest adjustment system;

3) a sternum strap that serves as a balance between the shoulder straps;

4) well-placed shoulder straps that correspond to the curvature of the shoulder;

5) well-placed hip belt;

6) a design with an outer frame;

7) a back ventilation system;

8) size and shape that corresponds to the size of the user's body ( $<60$ litres for small body sizes and $>60$ litres for large body size);

9) backpacks frame made of strong and lightweight material:

10) strong and lightweight fabric for the backpack bag;

11) the backpack bag should be sealed neatly and tightly to ensure waterproofness.

In addition, it is important to:

1) choose the right size of backpack according to the body type (this is why backpacks need to have adjustable straps and belts);
2) properly pack (a person shouldn't carry weight larger than $20-25 \%$ of his/her body weight; light items should be packed at the bottom and the heaviest equipment should be placed close to the back, above shoulders);

3) choose a backpack with a high-quality back pad (maximal freedom of movement, even weight distribution, reduction of pressure on shoulders).

\section{B) Anthropometric measurements}

In the design process, a more extensive anthropometric analysis was necessary in order to provide customization for users with different physical characteristics.

The measurements were taken from the 95-th percentile of males and 5-th percentile of females (Figure 1, Table 4) in order to create a design suitable for $95 \%$ of potential users.

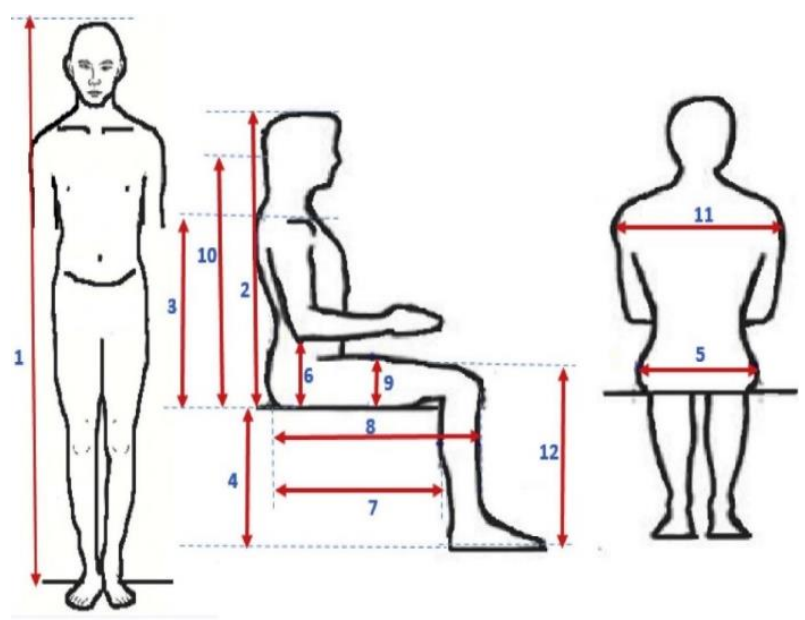

Fig. 1. Anthropometric measurements

Table 4

Anthropometric measurements, 95-th and 50-th PCTL male, 5-th PCTL female (dimensions given in $\mathrm{cm}$ )

\begin{tabular}{llccc}
\hline \hline No. & Description & $\begin{array}{c}95 \\
\text { male }\end{array}$ & $\begin{array}{c}50 \\
\text { male }\end{array}$ & $\begin{array}{c}5 \\
\text { female }\end{array}$ \\
\hline 1 & Body height & 181 & 171 & 160 \\
11 & Shoulder width & 46.2 & 42 & 38 \\
5 & Hip width & 38 & 32 & 27 \\
12 & Distance - knees to feet & 57 & 53 & 49 \\
8 & Distance - hips to knees & 61 & 56 & 46.6 \\
3 & Shoulder height & 62 & 57 & 52 \\
\hline \hline
\end{tabular}




\section{DEFINING USER NEEDS AND DESIGN REQUIREMENTS}

According to Cleverhiker [8], the most visited mountain hiking web site, there is a list with basic requirements of buyers of mountain backpacks:

1) Price - the backpack should be worth the investment and last for many years and miles.

2) Weight - a good balance between weight, comfort and durability is needed (reducing its weight reduces the overall load hikers carry).

3) Frame - the frame shouldn't add weight, simple frames that are comfortable for carrying up to $16 \mathrm{~kg}$ are a good choice.

4) Volume - 40-50 litres pack is sufficient for fitting all gear, with a need for increasing the volume for winter trekking due to bulky winter gear.

5) Design - simple and rational design makes the best backpacks.

6) Material - most backpacks are made from one of two durable materials: Ripstop Nylon or Dyneema Composite Fabric (DCF is lighter and more water resistant, but also more expensive).

7) Fit - comfort is one of the most important factors, therefore the right dimensions and adjustability of the backpack are crucial.

Taking this list into consideration, the designer requirements are clearly defined. The designed backpack should be:

- with a simple and practical design focused on efficiency of the components;

- consisted of modular parts in order to enable better functionality and easier use;

- multi-functional in order to meet as many user requirements as possible;

- with an adjustable: back pad, hip belt, shoulder straps and sternum strap, in order to provide maximal ergonomics;

- with an appropriate frame that will distribute the load forces and reduce the pressure on the shoulders;

- with a volume of $40-50$ litres with possibility for increasing up to 70 litres;

- made out of durable materials.

\section{DESIGN OF A COMPACT, MULTI-FUNCTIONAL MOUNTAIN HIKING BACKPACK}

Taking into consideration all the gathered information and the defined designer requirements, the next step was generating ideas and developing the design of the backpack.

\section{a) Generating concepts}

Several concept designs were elaborated through sketching (Figures $2-4$ ) and then finally compared and graded according to the most important criteria: comfort, ergonomics, compact design, multi-functionality, modularity, capacity, materials and design. The best concept was selected for further development (Figure 5).

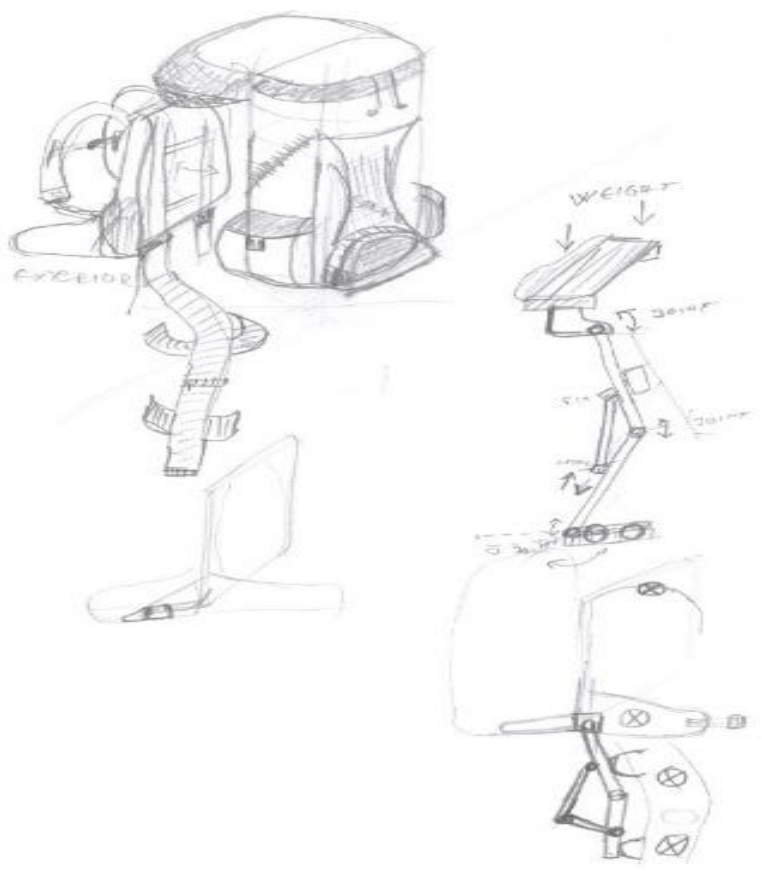

Fig. 2. Concept 1

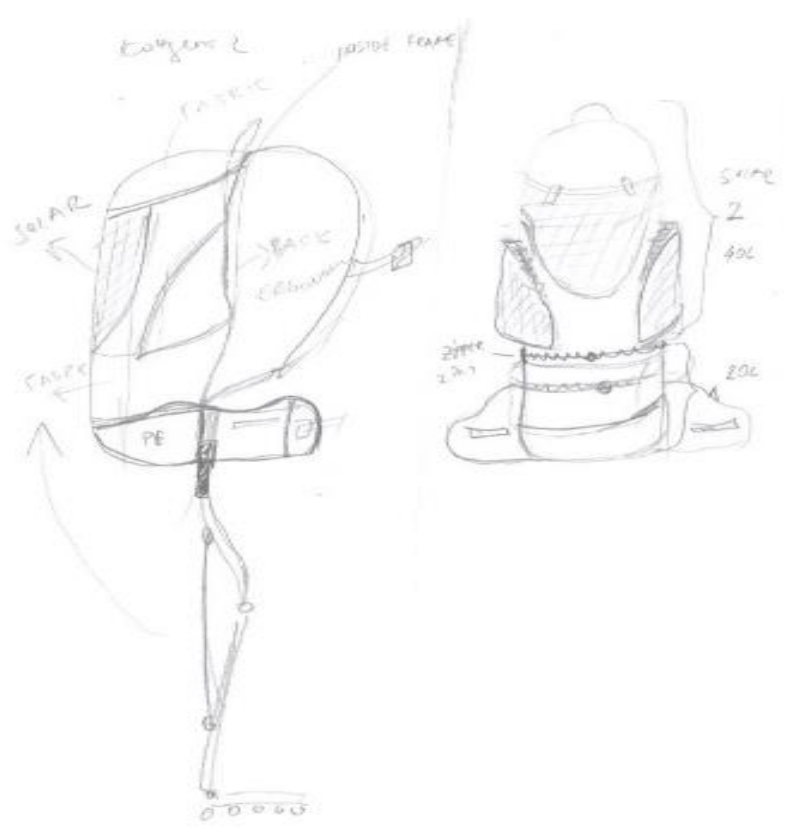

Fig. 3. Concept 2 


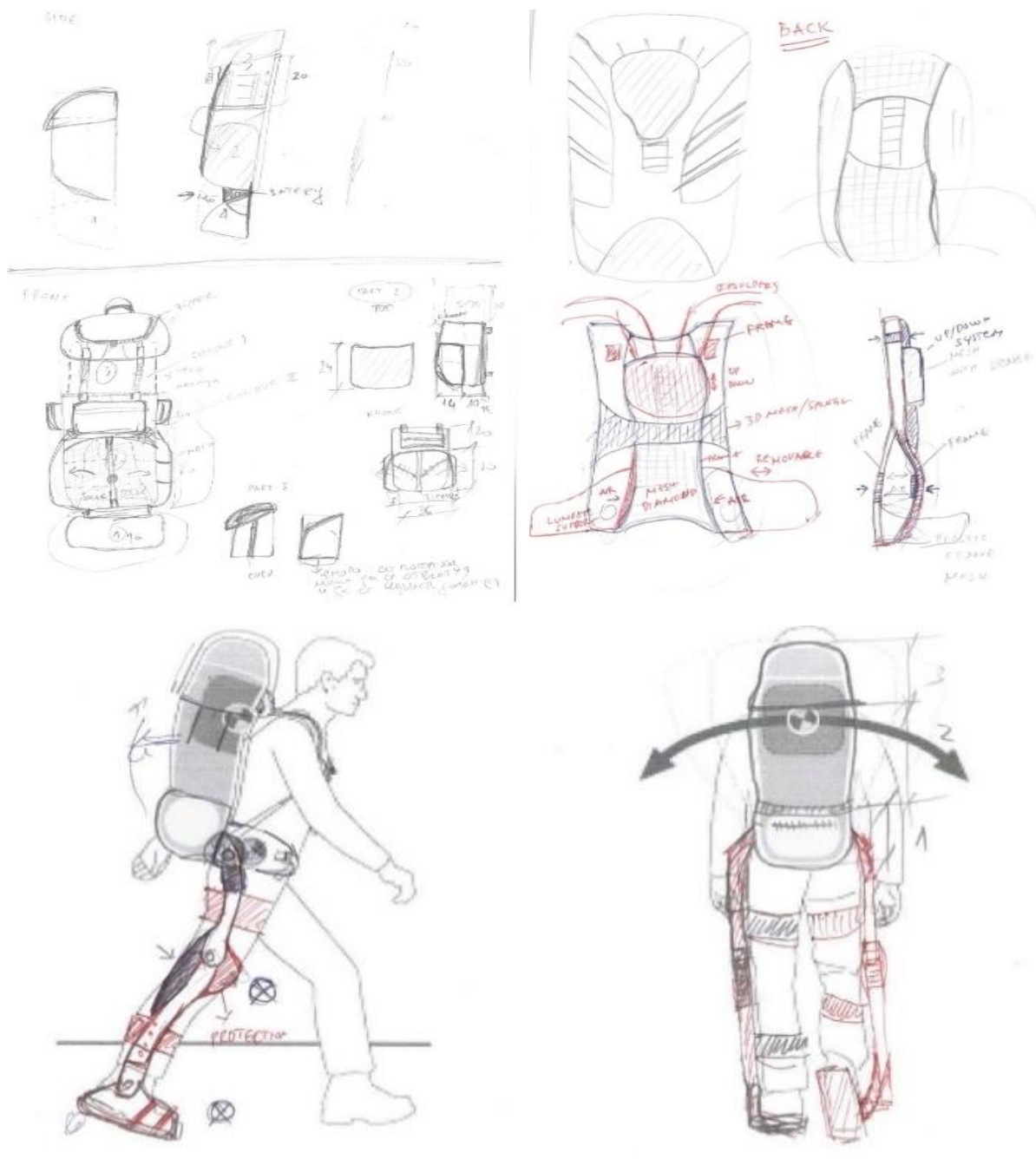

Fig. 4. Concept 3

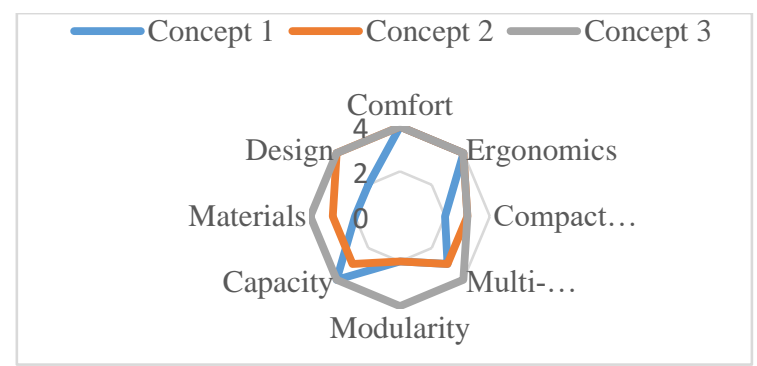

Fig. 5. Concept evaluation using the spider mesh diagram

\section{b) Further development of the selected concept}

The final design is a backpack built out of 5 independent modules which have individual functions (Figure 6; Table 5). When joined together, the modules obtain the final purpose of the product. As the examples found in nature, the modular design enables simplified increasing in size, form and function and easy adjustment to different external conditions. Because the parts are independent they can be produced in different locations and therefore possibly reduce the overall production cost compared to traditional production processes. In addition, any issues with one component can be solved by its replacement instead of replacing the whole product which prolongs the life expectancy of the product.

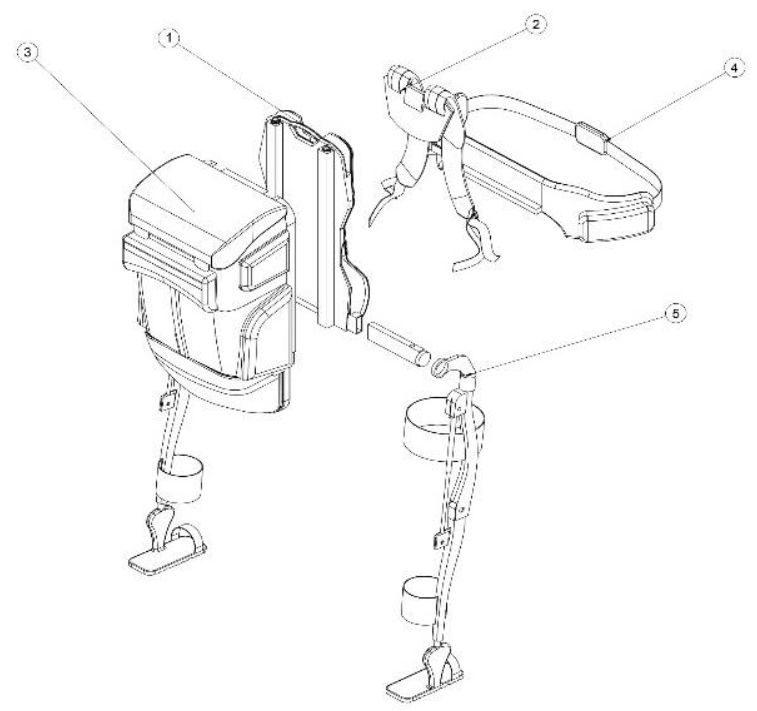

Fig. 6. Exploded view of the backpack modules 
T a b l e 5

Basic modules of the designed backpack explained

\begin{tabular}{cl}
\hline \hline No. & Description \\
\hline 1 & External frame with ergonomic back plate \\
2 & Shoulder straps \\
3 & Backpack \\
4 & Lumbar support belt \\
5 & Exoskeleton \\
\hline \hline
\end{tabular}

The 5 independent modules are:

1) External frame with ergonomic back plate (Figure 7)

The outer frame is designed to detach the backpack from the body. It has an ergonomic design following the natural curvature of the spine. It is covered with a soft sponge and 3D air mesh fabric for air circulation and comfort. Airflow and air contact systems prevent the body from sweating. This frame is a base, with guides on which different types of backpacks (with their own external frames) can be attached.

\section{2) Shoulder straps (Figure 8)}

The shoulder straps are also designed as a separate component that is attachable to the external frame by straps and Velcro. There are 5 levels of height adjustment for the shoulder straps so that they can be used by different types of users without ruining the ergonomic features. The shoulder straps contain a sternum strap for additional fixation and security, with incorporated plastic slider components for obtaining of length adjustability.

\section{3) Backpack}

Inspired by the ways in which natural organisms have perfected their adjustment to the external factors by adapting their size and led by the user requirements for maximum use of volume and multifunctionality, the backpack was designed with an adjustable volume. Like the pangolins or armadillos, this backpack unfolds to release additional volume. The basic part has a size of 40 liters, built with a bottom plate made of cross-linked polyethylene for maximum stiffness and damage protection (Figure 9). When a larger size is needed, the bottom zipper opens to release additional 15 liters (Figure 10). In order to obtain extra 20 liters, there is an internal mechanism for vertical extension which serves for lifting the top and achieving the final volume of 75 liters (Figure 11). The backpack has an outer frame for attaching to the basic frame with the back plate. In addition, the design of the backpack frame allows vertical sliding of 5-6 cm when the hiker is moving and this sliding helps to reduce the load forces and weight on the shoulders by $60 \%$.

\section{4) Lumbar support belt (Figure 12)}

This belt is intended to be used when the backpack is heavily loaded. It can be attached to the external frame and when used it changes the gravity of the whole backpack, and therefore, it also changes the load forces on the body. It has been calculated that when using a lumber support belt of over $80 \mathrm{~cm}$, the load on the body is reduced by $15 \%$.

\section{5) Exoskeleton}

The exoskeleton is based on a bionic principle and it has a purpose to transfer the entire weight from the shoulders and hips to the shoes. It also supports the body and gives it extra strength. Natural exoskeletons (like the ones found on insects and crabs) are an external body cover for some invertebrates which provide support and protection. In this case, the exoskeleton is used to increase the physical capabilities of the backpack users and ergonomic features of the backpack itself. The exoskeleton is simple to mount on the external frame by screwing it to the shaft (Figure 13). The mechanism is customizable for each user. There is an option for horizontal adjustment of the upper part and 2 points of vertical adjustments among the legs.

The whole exoskeleton can be fastened to the legs in 2 spots and fastened to the shoes in 1 spot. It is meant to be attached on the outside of the legs and it follows all the natural functions of the legs movement, kneeling, running etc. The exoskeleton can be folded when not being used (Figure 14).
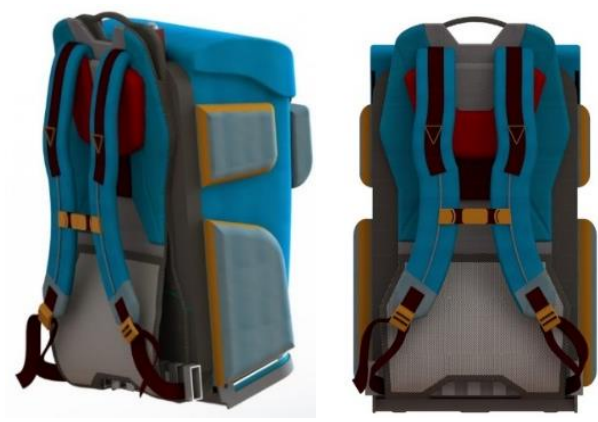

Figs. 7-8. Back view of the basic external frame with shoulder straps and backpack attached

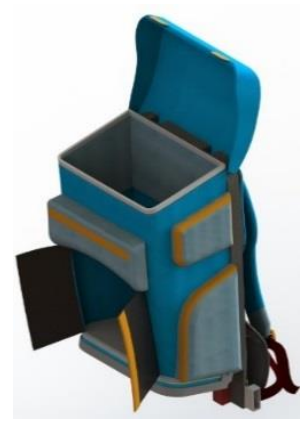

Fig. 9. Backpack 40 liters

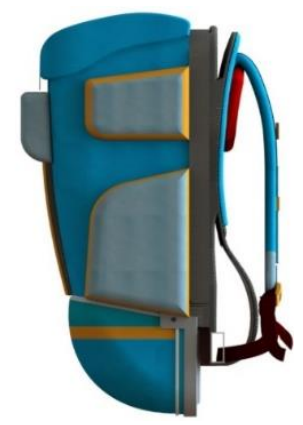

Fig. 10. Backpack 55 liters 


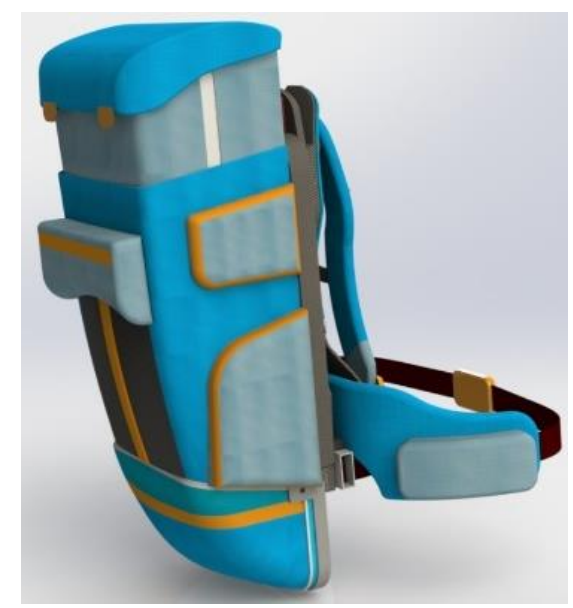

Fig. 11. Backpack 75 liters

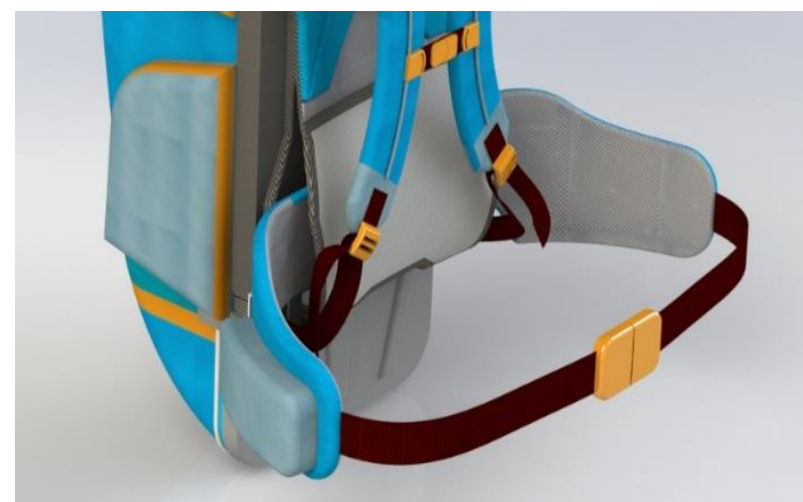

Fig. 12. Lumbar support belt

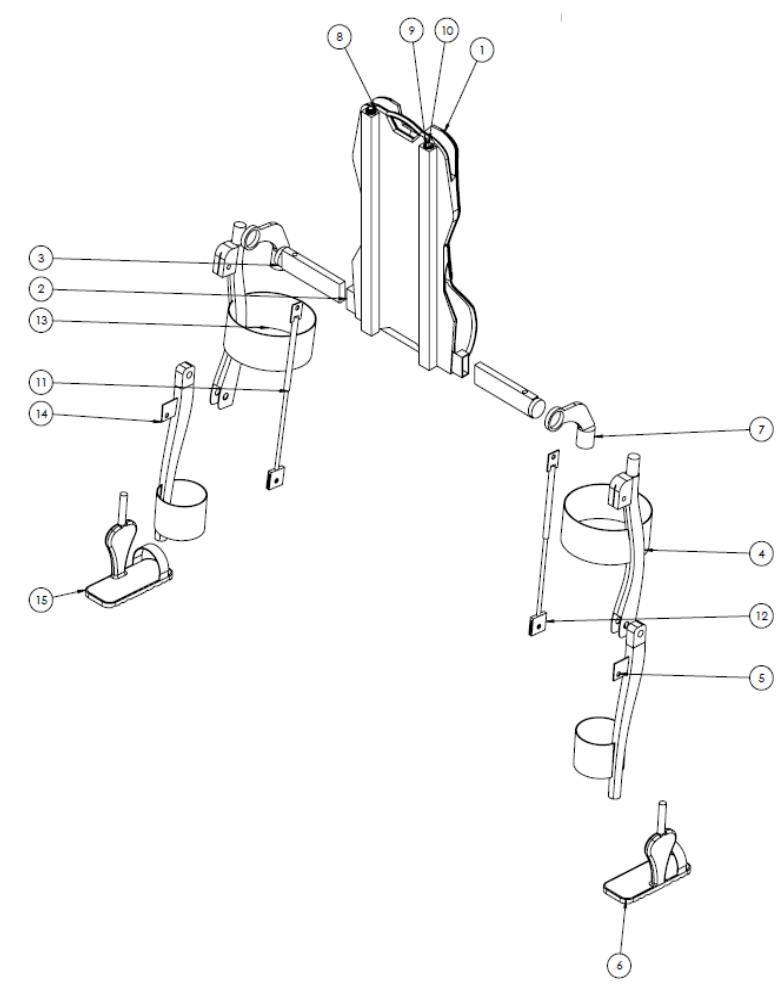

Fig. 13. Exploded view of the exoskeleton components and the way they are attached to the basic external frame

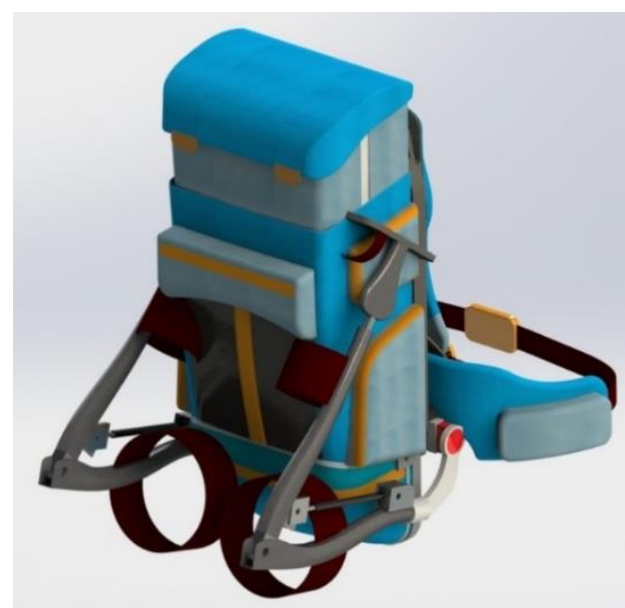

Fig. 14. Folded exoskeleton

Multi-functionality of the design is also achieved by additional functions to some of the components. There are solar panels installed on the front side and batteries that provide energy for charging electronic devices or LED lamps (Figure 15).

Another key feature is the special designed structure of the exoskeleton, that could be easily transformed to be used as a base construction for a one person tent (Figures 16 and 17).

By thinking about additional features of the components the value of the design is increased, the backpack is brought closer to the needs of the target users. This means they would be willing to invest in it and used for many years.

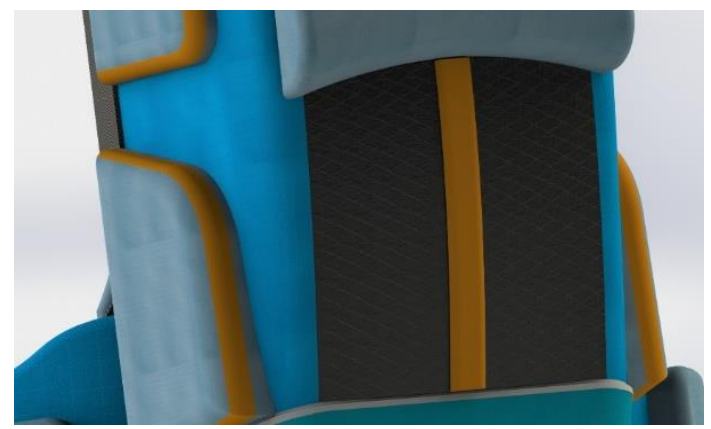

Fig. 15. Solar panels installed at the front of the backpack

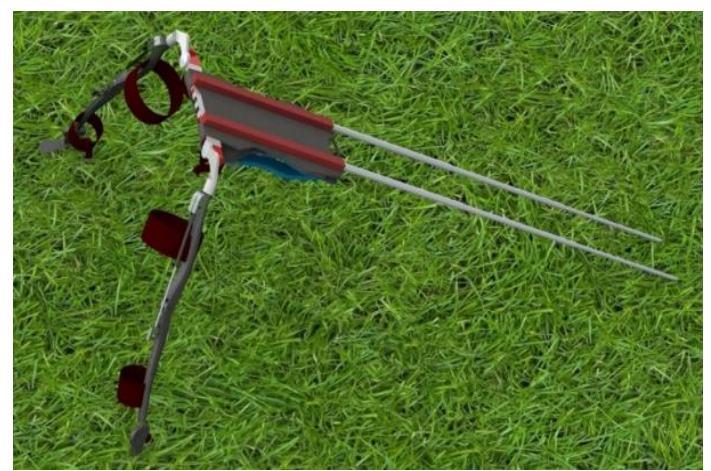

Fig.16. Use of the exoskeleton as a tent construction 


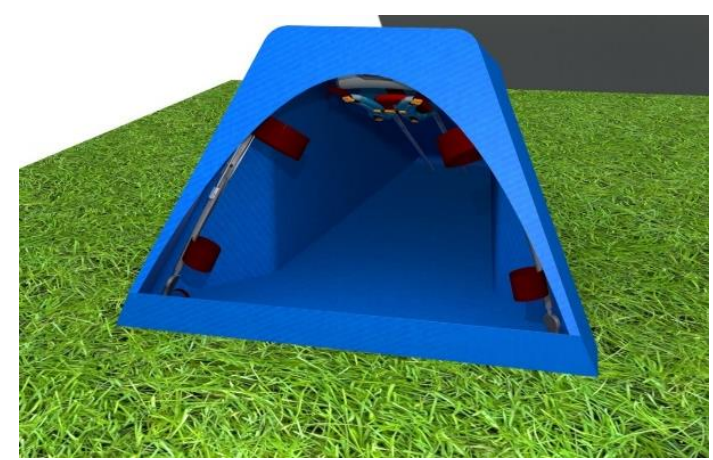

Fig. 17. Use of the exoskeleton as a tent construction

\section{CONCLUSIONS}

The main goal of this research was to suggest design methods for creating products that are compact, modular, multi-functional and have adjustable shape and size. Creating such products is in favor of the circular design economy which challenges designers to think about maintaining a loop life cycle of items by: extending their utilization period, making them multi-functional, easier for manufacturing, suitable for reuse and repair etc.

For successful achievement of the main goal, an in-depth analysis of bionic principles related with the mentioned characteristics was done. Bionics as an interdisciplinary field offers inexhaustible inspiration for solving problems in many different industry branches.

The design methods were used to propose a concept for a mountain hiking backpack with maximum utilization of its volume in order to fit as much equipment and tools as possible and enable carrying larger weights without causing discomfort and pain to the user. Seeking inspiration in nature, as well as analyzing the ergonomic requirements, user preferences and latest technologies were important for offering a backpack that has improved functional and ergonomic features. The designed backpack takes the users experience to the next level, offering: adjustable volume; independent modular components that can be used and combined together according to needs; system for reduction of the load forces on the body, therefore reducing pain in the back and shoulders; additional features including ecological production of electric energy sufficient for charging of electronic devices and using a part of the main structure for building a tent.

The conclusions drawn from this research can be used as an example or starting point for other designers that seek a way to provide multi-functionality and space optimization.

This paper also emphasises the importance of conducting thorough researches on all aspects relevant to the given problem and applying all available technological and scientific achievements in order to reach the best result.

\section{REFERENCES}

[1] Parkinson, A. R., Balling, R. J., Hedengren, J. D.: Optimization Methods for Engineering Design: Applications and theory, Brigham Young University, 2013.

[2] Ericsson, A., Erixon, G.: Controlling Design Variations: Modular Product Platforms, Modular management AB and Society of Manufacturing Engineers, 1999.

[3] Fourt, Lyman; Hollies, Norman: Clothing: Comfort and Function (Fiber Science), Dekker (Marcel), 1971.

[4] Coelho, D. A., Versos, C. A. M.: A comparative analysis of six bionic design methods, International Journal of Design Engineering, 4 (2), 114-131 (2011).

[5] Helms, M., Vattam, S. S., Goel, A.: Biologically inspired design: process and products, Design Studies, Vol. 30, No. 5, pp. 606-622 (2009).

[6] Ball, P.: Patterns in Nature: Why the Natural World Looks the Way It Does, University of Chicago Press, 2016. https://www.amazon.com/Patterns-Nature-Natural-World -Looks/dp/022633242X

[7] Retnari Dian, M., Velahyati, A., Hartati, H.: Desain Backpack Berdasarkan Analisis Biomekanika dengan Pendekatan QFD dan TRIZ untuk Pendaki Wanita, Hasil Penelitian Fakultas Teknik, Grup Teknik Mesin, Universitas Hasanuddin, Vol. 5, pp. 1-12 (2011),

[8] Cleverhiker: 10 Best Lightweight Backpacks of 2019, (2019), www.https://cleverhiker.com/ 
